\title{
Experimental access to associative learning in honeybees
}

\author{
J Mauelshagen, U Greggers
}

Institut für Neurobiologie, Freie Universität Berlin, Königin-Luise-Str 28/30, 1000 Berlin 33, Germany

(Received 29 October 1992; accepted 14 April 1993)

\begin{abstract}
Summary - The pioneering work on the behavior and physiology of bees provides a fundamental framework on which new experiments can be designed in order to investigate the nature of associative learning in bees. Such studies require investigations not only on the behavior of free-flying bees, but also on the behavior of restrained bees as a basis for studies on the cellular level. In order to combine the results about free-flying bees with the results obtained in the laboratory, it is first necessary to test the validity of the restrained preparation. Therefore, one has to deal with the clarification of associations formed during both classical conditioning and instrumental learning. If it is possible to identify comparable associations, then the results could lead to mutually supportive interpretations with respect to the mechanisms and biological meaning of learning and memory in the honeybee.
\end{abstract}

Apis mellifera / instrumental learning / classical conditioning / associative learning

\section{INTRODUCTION}

Honey bees (Apis mellifera $L$ ) are a wellknown model for behavioral studies of learning and memory (Opfinger, 1931; Lindauer, 1963; von Frisch, 1967; Gould, 1984; Menzel, 1990). Individual bees have to remember several parameters regarding effective food sites, such as their location, color, odor and shape. As social insects bees are well suited for an investigation of the mechanisms underlying memory formation. Despite their high learning capabilities, insect brains also provide access to studies at a cellular lev- el (Menzel et al, 1991). Therefore, to investigate learning and information processing in the bee brain, different methods are applied, such as studies on the behavior of free-flying bees (Lindauer, 1963; von Frisch, 1967; Menzel et al, 1974; Gould, 1984; Bitterman, 1988; Menzel, 1990; Greggers and Menzel, 1993) and on the learning behavior of restrained bees ( $\mathrm{Er}$ ber and Schildberger, 1980; Bitterman et al, 1983; Menzel and Bitterman, 1983; Smith, 1991; Smith et al, 1991; Menzel et al, 1993). Furthermore, electrophysiological studies are carried out, which allow the application of simple learning paradigms during extracellular recordings (Rehder, 
1987; Smith and Menzel, 1989a, 1989b; De Jong and Pham-Delegue, 1991; Braun and Bicker, 1992) or intracellular recordings (Erber, 1980, 1981, 1983; Hammer, 1991, 1993 submitted; Mauelshagen, 1993). Essential support is provided by morphological (Mobbs, 1982; 1984, 1985; Rybak, 1987; Rehder, 1988, 1989; Rybak and Menzel submitted), pharmacological (Mercer and Menzel, 1982; Mercer et al, 1983; Michelsen, 1988; Braun and Bicker, 1992; Wittstock, 1993) and immunocytochemical studies (for review see Bicker, 1993). The most recent progress has come from introducing new techniques, ie patch clamp recordings on an identified neuronal population in the bee brain (Schäfer et al, 1993), optical recordings (Lieke, 1991, 1993) and biochemistry (Altfelder and Müller, 1991; Altfelder et al, 1991; Müller and Altfelder, 1991). Thus there is a kind of fragile framework which is composed of some pioneering and some very specific studies; however, the pieces often do not fit and some fundamental questions have only been partly addressed.

In this review, 2 approaches are emphasized: behavioral studies on the foraging behavior of free-flying bees and the electrophysiology of single neurons in the bee brain during application of simple learning paradigms which is based on a restrained preparation. To focus attention on some basic problems, the relevance and validity of both approaches is discussed.

\section{THE PROBLEM}

Studies of learning and memory in honey bees need to analyze the kind of associations which are formed during foragingrelated behaviors and the mechanisms which underlie such associations. An ex- perimental situation has to be designed to extract the relevant parameters which might be strong indicators of a learned behavior. Basically, there are 2 approaches in studying the behavioral components of honeybee learning. The observation of free-flying bees leaves the bee in the most natural conditions, with the disadvantage that the experimental situation is less controlled; in the other approach, the animal is restrained so that only single components of the natural behavior can be studied, but with the advantage of a well-controlled experimental situation. On the basic knowledge of learning theories, however, one runs into the problem of eventually studying 2 different aspects of learning (Menzel and Bitterman, 1983), ie with free-flying bees learning based on an operant behavior (instrumental learning) is studied; with restrained bees learning based on Pavlovian (classical) conditioning is investigated (Bitterman et al, 1983).

During instrumental learning one has to consider 3 important parameters: a behavioral response, $\mathrm{R}$; a positive or negative outcome, $\mathrm{O}$, of this response (reinforcer); and a stimulus, $S$, which are present during this contingent event (Colwill and Rescorla, 1986). Thus associations would be possible between the stimulus and the response (stimulus-response associations), between the response and the reinforcer (response-reinforcer associations) or both (2-process theory). Although there are good reasons to believe that, at least for vertebrates, the most effective associations are formed between the response and the reinforcer, there are still some uncertainties about it, in particular as regards the interpretation of the involvement of the stimuli.

During classical conditioning (Pavlov, 1927) a conditioned stimulus (CS) becomes predictive for an unconditioned stimulus (US). After conditioning (pairing of $\mathrm{CS}$ and US) the conditioned stimulus elic- 
its the conditioned response (CR) which resembles the response to the unconditioned stimulus (UR) before conditioning. Thus the conditioned response is the consequence of a stimulus-stimulus association (ie stimulus-reinforcer association). Usually a conditioned response develops within multiple conditioning trials, but there are also a few examples which report a high learning rate after only a single conditioning trial (Menzel et al, 1974; Sahley et al, 1981; Crow and Forrester, 1990).

Therefore, the most striking difference between the 2 experimental approaches with honey bees is that learning in freeflying bees is a consequence of their decisions during foraging, while with restrained bees learning is a stimulus-induced behavior, whereby the temporal relation and selection of the stimuli are determined by the experimenter.

\section{THE "FREE-FLYING" APPROACH}

Considering an individual bee which has been trained to collect sucrose solution from a feeding place, what are the associations the bee needs in order to reliably identify this feeding place, to distinguish it from other food sources and to evaluate its efficiency? It is well known that free-flying bees can learn the location, color, odor and shape of a food source and the time of day at which an efficient reward can be obtained (Opfinger, 1931; Lindauer, 1963; Gould, 1984; Bitterman, 1988; Menzel, 1990). But this does not automatically imply that the presented stimuli are directly associated with the reward itself or with the behavior which can be composed of several parameters such as flying to or away from the food source, sitting down, handling, extending the proboscis etc.

Opfinger (1931) first addressed the question of when, during visiting a feeding place (during arrival, sucking or departure), bees learn the cues that characterize the stimuli and/or landmarks of the feeding place. She found that colors and landmarks were learned best during the arrival flight and hardly at all on departure, while Gould (1986) claimed that colors were learnt only on arrival and close land-marks only during the departure flight. The learning of colors at a feeding place was further studied by Menzel (1968), who more quantitatively determined the time dependencies of colors presented during arrival flight or during sucking. He suggested that bees can learn colors both applied during arrival and during sucking. Those studies indicated that learning about a food source could be phase-specific. This was supported by the experiments of Grossmann (1970, 1971), who concluded that the color during arrival significantly dominates the color during sucking. He found that learning about the sucking color had an influence only on the number of approach flights, but not on the decision to land on the sucking color during the test phase. Furthermore, he reported that the arrival color was learned faster, if both arrival color and sucking color were the same, suggesting at least some learning about the sucking color itself. If an odor was added, learning was significantly increased, even if arrival and sucking were delayed by more than 8 s. Most importantly, Grossmann (1971) showed that despite perfect contiguity colors could not be learned passively, ie by just seeing the color a sufficient amount of time before sucking rather than during the arrival flight. Learning about colors and/or landmarks present only during departure was reported by Hannes (1930) and was studied systematically by Lehrer (1991), who interpreted her results as excitatory backward conditioning. Couvillon et al (1991) studied learning of stimuli on arrival and departure by emphasizing the question of when, during a visit at a feeding 
place, bees learn about its location. They concluded that bees learn both during arrival and departure, and that there was no phase-specific preference for learning colors or landmarks. However, as they correctly concluded, the learning on departure cannot be readily interpreted as backward conditioning, but that other parameters such as associations with interceptive stimuli have to be considered. Thus the question of the nature of the associations remains unsolved by the studies described above.

Other investigations tried to unravel this problem by closely relating the learning experiments with bees to those performed on vertebrates (Grossmann, 1973; Sigurdson 1981a, 1981b; Bitterman, 1988). Many theoretical paradigms developed for the studies on vertebrates have also been successfully applied to the bee. The application of fixed ratio and fixed interval schedules as developed by Skinner (1938), for example, were shown to have the same effects as training vertebrates (Grossmann, 1973, Sigurdson, 1981a, 1981b; Bitterman, 1988). Thus, phenomena such as resistance to extinction, the overlearning-extinction effect, successive negative incentive contrast, conditioned inhibition and within-compound associations were found to parallel the results in the vertebrate literature (Bitterman, 1988).

Further experiments will be challenged by controlling an experimental situation so that extracting the relevant parameters becomes possible. One recent study which allows controlled access to the informational components may offer at least the necessary conditions to analyze the nature of associations during foraging by a single bee (Greggers, 1989; Greggers and Menzel, 1993). In this study single bees were trained to collect sucrose solution in a patch of 4 electronic flower dummies (feeders). As an input function for analyzing the system the learning ability of the bee was challenged by using a dynamic reward situation. In contrast to traditional experiments using a static reward system by offering unitary rewards in dual choice experiments (Staddon, 1983), differently rewarded feeders with a constant flow of sucrose solution were applied in a multiple choice situation in this study. As a consequence of the bee's visiting all of the 4 feeders the amount of sucrose solution obtained depends on the sequence and frequency of visits at each feeder. Therefore, the bee experiences graded rewards during the moment-to-moment decisions (fig 1). In different experimental arrangements concerning reward rates and color marks of the feeders, the behavior of the test bee was monitored by a computer in real time with several photodetectors installed in each feeder. This is the first successful technique for analyzing a number of very relevant parameters such as the sequence and frequency of visits to each particular feeder, the handling time and lick time during each visit and the flight time between successive visits. Thus one has the powerful tool to manipulate the experimental parameters in order to determine which stimuli and which of the choice- and time-related parameters may be relevant for the learning process.

To test how the bee's choice behavior corresponds to the average amount of reward, the data from patches with different reward rates were compared to data from experiments with equal reward rates. No difference was found between the choice frequencies of 4 equally rewarding feeders. These results demonstrate that feeders with the same sucrose solution flow rates are chosen equally frequently. This is true irrespective of whether the feeders are marked with the same or different colors or odors, and thus are distinguishable either both by color or odor and location, or by location alone. Therefore, if there are associations between the stimuli and the ob- 


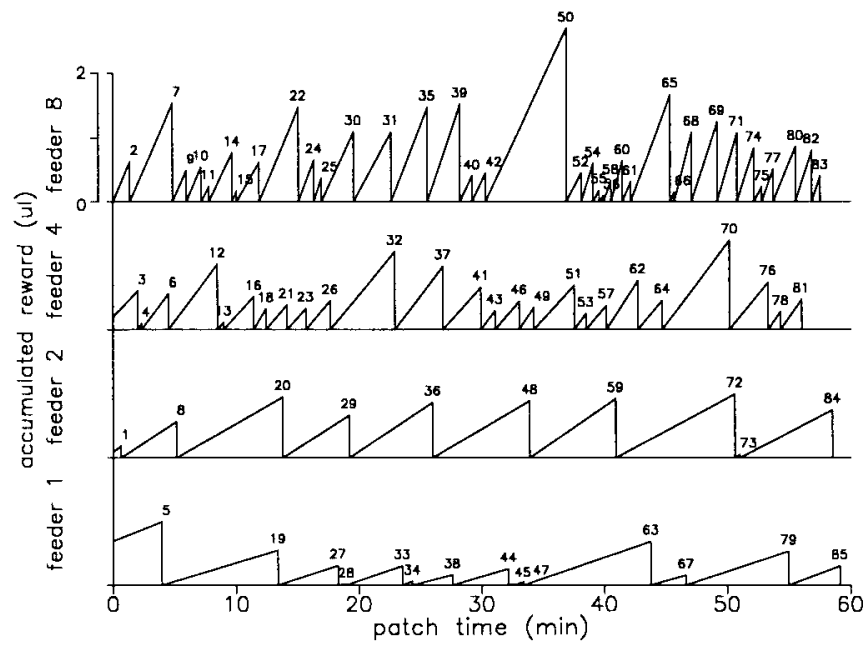

Fig 1. Sequence of visits of an experimental bee at the 4 feeders $(1,2,4,8)$ during one foraging bout which lasted $57 \mathrm{~min}$ (abscissa). The successive visits are indicated by ascending numbers. The flow rates of sucrose solution in the 4 feeders differed: $0.0625 \mu \mathrm{l} / \mathrm{min}$ in feeder $1,0.125 \mu \mathrm{l} / \mathrm{min}$ in feeder 2 , $0.25 \mu \mathrm{l} / \mathrm{min}$ in feeder $4,0.5 \mu \mathrm{l} / \mathrm{min}$ in feeder 8 . Thus, the ratios of the flow rates are 1:2:4:8; the same numbers coincide with the number tags of the respective feeders. The accumulation of the sucrose solution in each feeder during the inter-visit intervals is indicated by the rising slopes of the curves which differ for the 4 feeders because of their different flow rates. The bee sucks all the accumulated sucrose solution at any visit indicated by the reset of the rising slope. The effective reward at each visit can be read from the height of the function at each reset point. Note that even at the high reward feeders (feeders 4 and 8 ) the effective amount of reward may be very small if the time elapsing after the last visit is very short (taken from Greggers and Menzel, 1993).

tained reward, then those stimuli are equally effective for the formation of an associative memory. For groups with different reward rates, the test bee optimizes by partially matching its choice behavior to the reward rates of the feeders ie the bee chooses a higher reward feeder more frequently than a lower reward feeder (fig 2). This clearly demonstrates that the bee adjusts its behavior to the specific reward situation in the artificial patch.

Irrespective of the reward situation, a general phenomenon is the occurrence of 2 fundamentally different behaviors: any time the experimental bee leaves a feeder (actual feeder) it may either return to that feeder (stay flight), or choose one of the 3 alternative feeders (shift flight). The time dependencies of the 2 choice performances differ considerably in that the seconds immediately after departing from the actual feeder are dominated by fast stay flights. During these fast stay flights, the bee obtains only minute amounts of sucrose solution which makes the occurrence of stay flights surprising, because one would expect the bee to learn that this kind of choice is not successful. The most straightforward interpretation of this and other characteristics of the stay behavior would be that stay flights are not the consequence of an associative memory but rather reflect nonassociative components of the choice process. A further indication for 


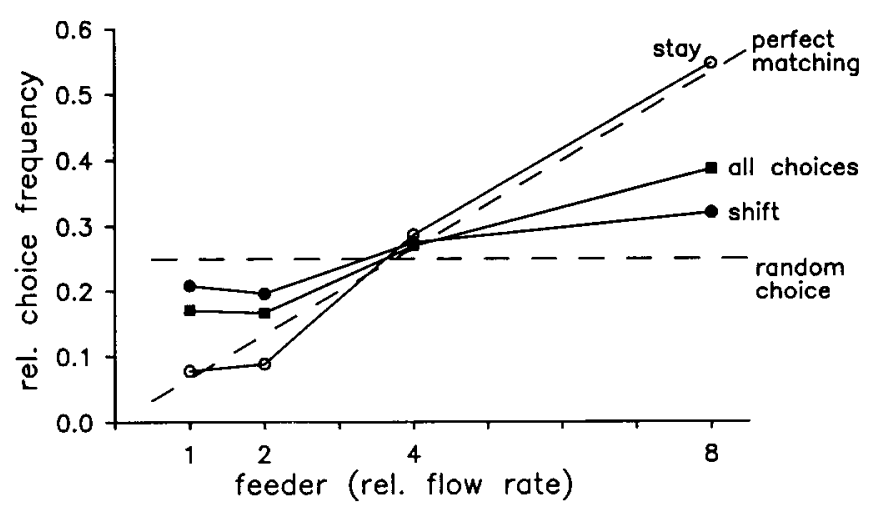

Fig 2. Event matching in an experiment with relative flow rates of 1:2:4:8 (solid lines). The dotted lines give 2 theoretical extremes of choice strategy: perfect matching and random choice. The curve marked by filled squares (all choices) gives the results for all choices; the curves marked by circles break down the choices into those resulting from stay (open circles) and shift (filled circles) flights. Number of all choices $n=3537$ of 8 bees (taken from Greggers and Menzel, 1993).

the existence of nonassociative memory components is taken from the analysis of the reward sequence during the momentto-moment decisions which shows that the actually experienced reward at a single feeder influences the information processing at the following feeder. For example, the lick time was shown to depend not only on the amount of reward offered by the actual feeder, but in addition, on the reward experienced during the preceding visits (table I). The associative components of the choice process can be analyzed by focussing on feeder-specific memories, ie components which can be isolated as behavior that is unique for each individual feeder. In this context the analysis of revisits to the same individual feeder after visiting one or more alternative feeders in between is especially suitable. Several parameters at the actual feeder (eg the lick time) can be shown to depend on the experience during the last visit to this same feeder, independent of the experience at the feeders visited in between. This suggests that a foraging hon- eybee learns the properties of a food source (its signals and rewards) so effectively that specific expectations guide the choice behavior. The results indicate that feeder-specific and feeder-unspecific memories are developed during the continuous

Table I. Indication of feeder-unspecific memory components.

\begin{tabular}{|c|c|c|}
\hline & \multicolumn{2}{|c|}{ Reward "actual" feeder } \\
\hline & Low & High \\
\hline \multicolumn{3}{|c|}{ Reward "last" feeder } \\
\hline Low & $\begin{array}{l}7.1 s \pm 0.8 \\
n=693\end{array}$ & $\begin{array}{l}14.9 s \pm 0.9 \\
n=1076\end{array}$ \\
\hline High & $\begin{array}{l}7.0 s \pm 0.6 \\
n=721\end{array}$ & $\begin{array}{l}18.5 s \pm 0.8 \\
n=769\end{array}$ \\
\hline
\end{tabular}

Lick time at the actual feeder of 8 bees ( $n=3537$ choices; low < $0.4 \mu$, high $>0.4 \mu$ ); last low-actual high versus last high-actual high is significant $(P<0.05$, paired $t$-test) (taken from Greggers and Menzel, 1993). 
learning process in the patch, which may be interpreted as associative and nonassociative components in the choice process, respectively.

On the basis of these data, further experiments have been designed to clarify the nature of the associations (see below).

\section{THE "RESTRAINED" APPROACH}

To control learning-relevant parameters, numerous studies have been performed on restrained bees (Kuwabara, 1957; Erber and Schildberger, 1980; Bitterman et al, 1983; Menzel and Bitterman, 1983; Menzel et al, 1991, 1993). Such studies have utilized the most biologically meaningful stimulus combinations, intending to compare the results obtained in this controlled situation with those obtained on free-flying bees (Menzel and Bitterman, 1983; Bitterman 1988). The best known paradigm is the classical odor conditioning of the proboscis extension reflex (PER, Kuwabara, 1957; Vareschi, 1971; Menzel et al, 1974). An odor serving as a conditioned stimulus (CS) is readily associated with a sucrose reward (unconditioned stimulus, US) delivered to the antennae and proboscis. After a single learning trial (CS/US pairing) there is a high probability of proboscis extension in response to the conditioned odor (conditioned response, CR). Experiments strongly suggest that the association formed by PER conditioning is classical (Bitterman et al, 1983). It has been demonstrated that concerning the rate of acquisition, generalization and differentiation and CS-US contiguity the results of proboscis extension conditioning have common characteristics with those obtained with free-flying bees (Menzel and Bitterman, 1983; Bitterman et al, 1983). Also the time dependencies of the conditioned response after 1-trial odor conditioning resembles the time dependen- cies of choice behavior of free-flying bees after a single training for color (Menzel, 1987). Despite all similarities, it is not clear whether the situations during which associations are formed are comparable and whether comparable neuronal changes occur. For example the classical conditioning of colors fails in restrained bees. The conditioning to mechanical stimulation or placement (Menzel, 1990), however, indicate that odors are not the only stimuli which can serve as CS in the restrained preparation.

The behavioral experiments on freeflying bees described above show that one can make quite specific predictions about the kind of memories applied by the bee during foraging. However, data on the acquisition, storage and retrieval of learned information can only be obtained by reducing the level of investigation. Therefore, it is especially important to study the exact time-dependencies of nonassociative and associative memories and the relative contribution of nonassociative components to associative memory consolidation (Menzel et al, 1993). Further, the brain structures which are involved in memory formation have to be determined, the cells which are involved and finally the cellular mechanisms by which such complex behavior can be realized.

The successfully applied PERconditioning to odors serves as a basis for studies on reduced preparations. Using this paradigm, it is concluded that learningevoked changes in the response behavior of single cells must be due to the modulation of the odor processing pathway. This is possible at sites of convergence of the $\mathrm{CS}$ and US processing pathways (fig 3 ). Odors are processed via the antennoglomerularis tracts (agt) which relay information from the antennal lobes to the mushroom bodies (Mobbs, 1985). So far, only 1 component of the sucrose processing pathway is known, the VUMm $\times 1$ - 


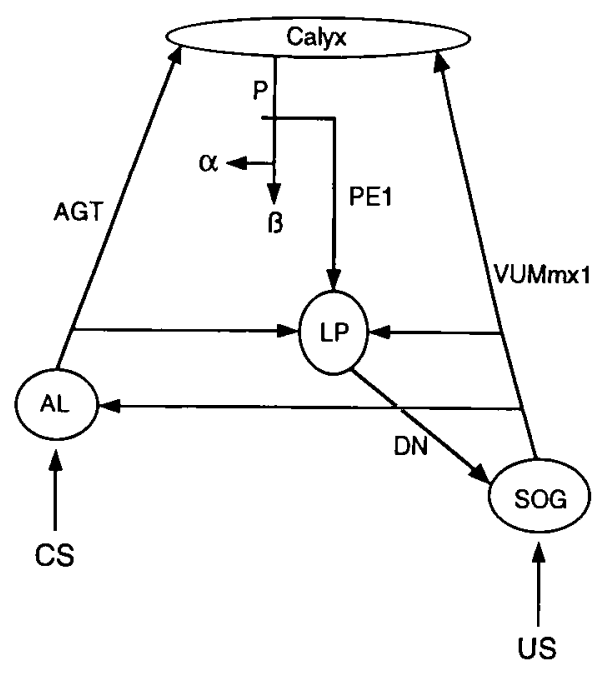

Fig 3. Schematic diagram illustrating the projection areas of the CS and US pathways, their possible sites of convergence and the position of the PE1 neuron within these pathways. AL: antennal lobes; AGT: antenno-glomerularis tracts, the relay neurons from the antennal lobes to the mushroom bodies; SOG: subesophageal ganglion, VUMm $\times 1$ : single neuron of the US-reinforcer pathway, which originates in the SOG and has projection areas in the antennal lobes, in the lateral protocerebrum and in the calyces of the mushroom bodies; Calyx, $P, \alpha, B$ : calyces, pedunculus, $\alpha$-lobe and $\beta$-lobe of the mushroom bodies, LP: lateral protocerebrum, DN: hypothesized descending neurons. The PE1 neuron possibly transfers information from the pedunculus of the mushroom bodies to the lateral protocerebrum. The arrows indicate the probable direction of information flow (taken from Mauelshagen, 1993).

neuron (Hammer, 1991; submitted). It was shown that evoked spike activity in this neuron is sufficient to substitute for the sucrose reward during olfactory conditioning (Hammer, 1991, submitted). The projection areas of the VUMmx 1 neuron overlap with neurons of the odor processing pathway (eg agts) in the antennal lobes, the lateral protocerebrum and the calyces of the mushroom bodies. Thus the neural substrate for learning and memory in the bee brain appears to be distributed among several neuropilar regions. Therefore, neurons which are connected to these brain structures seem to be most interesting for the study of the cellular basis of learning and memory.

In bees, the involvement of the mushroom bodies in associative memory consolidation has been demonstrated using amnestic treatments. Thus the conditioned response probability was greatly reduced when the mushroom bodies had been treated shortly after a single learning trial (Menzel et al, 1974; Masuhr, 1976; Erber et al, 1980; Sugawa, 1986). Since an intracellular analysis of the mushroom body intrinsic Kenyon cells is not possible, single cell recordings have concentrated on the characterization of extrinsic elements ( $\mathrm{Er}$ ber, 1978, 1980, 1981, 1983; Homberg and Erber, 1979; Gronenberg, 1984, 1987; Homberg, 1984). A common feature of these neurons is their multimodality, ie most of them respond to more than one stimulus modality. Furthermore, in these pioneering studies adaptive changes of the response behavior of mushroom body output neurons were already observed during the application of different stimulus configurations.

The PE1 neuron is connected to mushroom body intrinsic Kenyon cells (Rybak, personal communication) and probably processes the information to the median and lateral protocerebrum. Despite its interesting projection areas, there are several advantages which make this neuron especially suited for a cellular analysis of information processing during learning (Mauelshagen, 1993): there is only one pair of PE1 neurons in the bee brain; the neuron seems to have a high integrative function, summing up the information of many Kenyon cells, which might possibly undergo changes in their response behav- 
ior during memory formation; it has a large dendrite, which provides the prerequisite for stable and repeated recordings; it has a well characterized electrophysiological signature, which allows identification before the experiment.

Reproducible high-quality recordings from a single neuron in the protocerebrum of the bee brain requires a reduced preparation (single head preparation) which leads to distortion of the proboscis extension reflex. Single heads in a less reduced state can show PER after a single learning trial, which suggests that the neuronal activity in single heads may be comparable to those in whole insects usually used for the behavioral analysis of PER conditioning. Therefore, the missing control over the behavioral indicator of the conditioned response has to be compensated by a sufficient amount of recordings during application of one experimental paradigm in order to statistically evaluate the response changes between groups. Nevertheless, the causality between neuronal changes and learning has to be subjected to future experiments.

In order to find correlates for nonassociative and associative memory processing, response changes due to stimulus paradigms for sensitization, 1-trial conditioning and differential conditioning were examined during repeated intracellular recordings from the PE1 neuron.

In a first series of experiments, paradigms which usually lead to proboscis extension in response to odors were applied: i) a sensitization procedure with stimulation of the antennae and/or proboscis with sucrose solution; ii) a t-trial conditioning procedure by pairing an odor (carnation) with sucrose solution (to antennae and proboscis); iii) a control group without sucrose stimulation. In a second series a differential stimulus paradigm was applied, in which 1 odor (carnation) was paired with sucrose and a second odor (orange) was presented unpaired. The odor responses of the PE1 neuron were evaluated as relative spike frequency changes between responses during test or training and the pretraining responses.

The results (table II) could be characterized by several points. In the same cell, there were measurable response changes due to both nonassociative (sensitization) and associative (conditioning) stimulus paradigms. Sensitization by antennal and proboscis sucrose stimulation had contrasting effects on the subsequent odor response in the PE1 neuron. This suggests that the processing of sucrose stimuli via antennae and proboscis is manifested in 2 qualitatively different pathways. The effect of compound sucrose stimulation to both antenna and proboscis (sensitization) on the odor response was different from the response change after 1-trial conditioning which uses the same sucrose stimulus. This indicates that the pairing-specific conditioning effect is due to a different evaluation of the compound sucrose stimulus. The fact that the effect of 1-trial conditioning on the odor response is very similar to that observed after proboscis sensitization suggests that the proboscis component of compound sucrose stimulation during conditioning might be dominant over the antennal component. The responsibility of the proboscis pathway for an evaluation of the sucrose reward has also been discussed for behavioral studies on restrained bees (Bitterman et al, 1983). During differential conditioning, there is a differential representation of the 2 odors, suggesting a learning-specific coding of odors in the mushroom bodies. Furthermore, this demonstrates that in the mushroom bodies, there is a differential information processing during nonassociative and associative memory formation. The up-and-down shifts of spike frequencies during differential conditioning are highly dynamic which might 
Table II. Results of intracellular recordings of the PE1-neuron during application of simple learning paradigms.

Response changes in the proboscis extension reflex (PER) and PE1 neuron

\begin{tabular}{|c|c|c|c|c|}
\hline Paradigm & Pretraining & Training & Test $(1 \mathrm{~min})$ & Test $(5 \mathrm{~min})$ \\
\hline \multirow[t]{3}{*}{ Sensitization } & $\begin{array}{l}\text { Carnation } \\
\text { PER: } 0 \\
\text { PE1: } 1\end{array}$ & $\begin{array}{l}\text { Sucrose antenna } \\
\text { PER: } 1 \\
\text { PE1: } 1\end{array}$ & $\begin{array}{l}\text { Carnation } \\
\text { PER: } 1 \\
\text { PE1: + }\end{array}$ & $\begin{array}{l}\text { Carnation } \\
\text { PER: } 0 \\
\text { PE1: } 1\end{array}$ \\
\hline & $\begin{array}{l}\text { PER: } 0 \\
\text { PE1: } 1\end{array}$ & $\begin{array}{l}\text { Sucr compound } \\
\text { PER: } 1 \\
\text { PE1: } 1\end{array}$ & $\begin{array}{l}\text { PER: } 1 \\
\text { PE1: + and - }\end{array}$ & $\begin{array}{l}\text { PER: } 0 \\
\text { PE1: } 1\end{array}$ \\
\hline & $\begin{array}{l}\text { PER: } 0 \\
\text { PE1: } 1\end{array}$ & $\begin{array}{l}\text { Sucr proboscis } \\
\text { PER: } 1 \\
\text { PE1: } 1\end{array}$ & $\begin{array}{l}\text { PER: } 1 \\
\text { PE1: - }\end{array}$ & $\begin{array}{l}\text { PER: } 0 \\
\text { PE1: } 1\end{array}$ \\
\hline Conditioning & $\begin{array}{l}\text { PER: } 0 \\
\text { PE1: } 1\end{array}$ & $\begin{array}{l}\text { Carn-sucrose } \\
\text { PER: } 0 / 1 \\
\text { PE1: } 1\end{array}$ & $\begin{array}{l}\text { PER: } 1 \\
\text { PE1: - }\end{array}$ & $\begin{array}{l}\text { PER: } 1 \\
\text { PE1: } 1\end{array}$ \\
\hline \multirow[t]{2}{*}{ Control } & $\begin{array}{l}\text { PER: } 0 \\
\text { PE1: } 1\end{array}$ & $\begin{array}{l}\text { Carnation } \\
\text { PER: } 0 \\
\text { PE1: } 1\end{array}$ & $\begin{array}{l}\text { PER: } 0 \\
\text { PE1: } 1\end{array}$ & $\begin{array}{l}\text { PER: } 0 \\
\text { PER: } 1\end{array}$ \\
\hline & & $\begin{array}{l}\text { Pretraining } \\
\text { 2nd trial }\end{array}$ & $\begin{array}{l}\text { Training } \\
5 \text { th trial }\end{array}$ & Test $(5 \mathrm{~min})$ \\
\hline \multirow[t]{2}{*}{$\begin{array}{l}\text { Differential } \\
\text { conditioning }\end{array}$} & $\begin{array}{l}\text { Carnation } \\
\text { PER: } 0 \\
\text { PE1: } 1\end{array}$ & $\begin{array}{l}\text { Carn-sucrose } \\
\text { PER: } 1 / 1 \\
\text { PE1: }-11\end{array}$ & $\begin{array}{l}\text { Carn-sucrose } \\
\text { Per: } 1 / 1 \\
\text { PE1: }+/ 1\end{array}$ & $\begin{array}{l}\text { Carnation } \\
\text { PER: } 1 \\
\text { PE1: } 1\end{array}$ \\
\hline & $\begin{array}{l}\text { Orange } \\
\text { PER: } 0 \\
\text { PE1: } 1\end{array}$ & $\begin{array}{l}\text { Orange } \\
\text { PER: (1) } \\
\text { PE1: } 1\end{array}$ & $\begin{array}{l}\text { Orange } \\
\text { PER: } 0 \\
\text { PE1: } 1\end{array}$ & $\begin{array}{l}\text { Orange } \\
\text { PER: } 0 \\
\text { PE1: } 1\end{array}$ \\
\hline
\end{tabular}

Listed are responses of the neuron to carnation before, during and after training: spike frequencies resembling the reference response level (1); relative frequency increases $(+)$; relative frequency decreases $(-)$ and occurrence of proboscis extension (PER) in comparable experimental behavioral situations: proboscis extension (1) or no response $(0)$. The spike frequency changes listed are significant with respect to the control group (Mann-Whitney $U$ test) or with respect to the unpaired odor (Wilcoxon test). 
be representative of different states of memory consolidation. So far, all observed response changes have been transient (in the minute range), suggesting that the PE1 neuron is not the site of long-lasting memory storage but rather might function as a monitor comprising the actual changes and dynamics during successive events of a continuous learning process.

\section{THE CONSEQUENCES}

The aim of the behavioral and the electrophysiological approach is to analyze the principal associations, their temporal components and mechanisms. However, several constraints should be noted: i) with respect to the theories on instrumental learning the interaction of the response, the reinforcer and the stimuli has not been clarified; ii) the learning phenomena observed with free-flying bees have only partly been addressed with restrained bees; iii) the results regarding the electrophysiology of identified neurons are limited by a shortlived preparation (lacking behavioral control), by the difficulty in recording repeatedly from small and single neurons and by the short recording time which does not allow access to long-term effects.

Thus all the results of experiments which are designed, performed and interpreted on the basis of the current knowledge are limited in their validity. In particular, it is of major importance to ascertain the role of the restrained preparation as a reliable source for studying the mechanisms which underlie learning phenomena.

The most successful strategy for solving this problem would be to identify those associations of free-flying bees which are most likely stimulus-reinforcer associations and which can be interpreted in analogy to the associative learning during classical conditioning. A second requirement is to isolate these associations from the re- sponse-reinforcer associations which obviously depend on the operant behavior of the free-flying bee. This leads to the hypothesis that restrained bees should only be able to form the stimulus-reinforcer associations, but fail to learn stimuli which are closely related to response-reinforcer associations (this could mean additional stimulus-response associations) or which are not related to the reinforcer itself (this could mean stimulus-stimulus associations, where the second stimulus is not the reinforcer).

It is obvious that the identification of these associations constitutes the most challenging task. The parameters which can be manipulated with free-flying bees are the specific selection of stimuli, the quality of the reward and, most importantly, the temporal relation between the stimuli and the reward.

For restrained bees it is well known that odors are readily associated with sucrose solution; colors, however, are not. With free-flying bees good learning for both odors and colors is observed. According to the above-mentioned hypothesis, this could indicate that with odors the bee forms stimulus-reinforcer associations, whereas with colors the bee forms stimulus-response associations. However, the question remains open of whether the process of restraining the bees simply suppresses the ability to learn colors. The assumption that in free-flying bees colors are not directly associated with the reward is, however, supported by the findings of Grossmann (1971) which show that passive learning of colors is not possible. This he managed by temporally isolating the stimulus from the response, but not the stimulus from the reinforcer. If this is true, the failure of color learning in restrained bees is no artefact. This could be the first hint that the failure of restrained bees to learn certain stimuli as specific predictors for food is a true consequence of the na- 
ture of associations in free-flying bees. Thus knowledge of associations in restrained bees might also possibly be transferable to the interpretation of results on free-flying bees.

To clarify the nature of associations the experiments on the optimization of a single bee in a patch of artificially arranged feeders (Greggers and Menzel, 1993) were modified. In this context one makes use of the specific associations between certain stimuli and the quality of the reward. A sensitive measure of such associations is the optimization by matching described above. All stimuli and close landmarks were removed by installing the setup on the roof of the institute and by arranging the 4 feeders in an open box facing the sky. In this situation optimization failed, ie the bee could not form differential memories depending on the different reward rates of the feeders. This opens the possibility for future experiments to introduce the stimuli separately. If the different stimuli are directly associated with the different reward rates and not only with their location, then the ability for optimization should be restored, even if the location of the stimuli together with their corresponding reward were rotated from visit to visit. Furthermore, the results should demonstrate whether the stimuli characterizing the location of the 4 feeders are learned only in a position relative to each other, ie learning of one location would depend on the arrangement of the other alternatives. Consequently, optimization would fail if the stimuli were not only rotated in the absence of other landmarks but also shifted in their relative position.

With restrained bees the correlation between performance and amount of reward has not been studied systematically. Dependencies of the conditioned response on modulations in US strength could be a principal rule underlying direct associations between stimuli and reinforcer. By testing this hypothesis with both free-flying and restrained bees using odors or other possible conditioned stimuli, one could obtain a sensitive measure of the validity of the restrained preparation. Preliminary electrophysiological results obtained by recording from the PE1 neuron indicate that on the neuronal level, there is a differential representation of 2 odors during differential reinforcement $(1 \%$ and $33 \%$ sucrose solution, respectively) which would again suggest direct associations between odors and sucrose solution.

Another approach to investigating the nature of the associations would be to perform an experiment analogous to that in the vertebrate literature. Colwill and Rescorla (1986) were successful in demonstrating response-reinforcer associations by applying the 'reinforcer-devaluation method'. Such evidence is based on differential training of 2 responses with 2 different reinforcers which otherwise share the same stimuli and location. After devaluation of 1 of the reinforcers in an independent situation, the rate of performance of 1 corresponding response should subsequently decrease in the case of a response-reinforcer association. However, the difficulties encountered in designing such experiments for the bee are obvious: one has to find 2 reinforcers which excite different reinforcing pathways in order to be selectively devaluated. It may well be that the only accessible reinforcing pathway is represented by the sucrose processing neurons via the proboscis. Furthermore, the 2 reinforcers should have the same subjective outcome for the bee which has to perform both behavioral tasks with the same effort. Thus before designing the critical experiments, elaborate tests would be necessary concerning the kind of responses and reinforcers and the adequate devaluation procedure. However, even control experiments could provide some insight into the simplicity or complexity of honey bee learning. 
If the above-suggested experiments are successful, and if it is possible to show that in free-flying bees at least the odors are directly associated with the sucrose reward and not (or not only) with the response, the location or even other stimuli which characterize the feeding place, then it would be possible to directly correlate results from restrained bees and free-flying bees. In this context, single cell recordings would be of major importance, since they might be a much more sensitive measure of the dynamics of memory processes than behavioral studies alone, reflecting not only the time course of the probability of proboscis extension in a yes/no fashion, but could perhaps also be correlated with some more finely-tuned behavioral components related to stimulus evaluation and expectation during memory consolidation or choice. Of course, to understand the role of single neurons such as the PE1 neuron, recordings of other cells are absolutely necessary, parallel to an extensive study on the connectivity of the complex network. Only then could cellular changes, such as the described response modulations of the PE1 neuron, which are divergent with respect to the stimulus configurations but convergent with respect to their time dependencies, be related to the behavioral components in a meaningful manner.

Therefore, it should be possible to determine the nature of the associations and their mechanisms, in order to acquire a precise knowledge of the temporal dynamics of memory formation by directly correlating experimental design and data obtained with the different but mutually supportive preparations.

\section{ACKNOWLEDGMENTS}

This review should provide encouragement to those individuals who consider their work on honeybee learning isolated from the natural lifehistory of bees. We would also like to acknowledge those people in this laboratory who supported our view that for an understanding of learning it is necessary to remember that learning has a biological meaning. We thank $\mathrm{P}$ Maher for improving the English manuscript.

\section{Résumé - Approche expérimentale de l'apprentissage associatif chez l'abeille domestique, Apis mellifera L. L'approche} multiniveaux présentée ici et appliquée à l'étude de l'apprentissage et de la mémoire des abeilles s'appuie sur 2 aspects fondamentaux du comportement d'apprentissage : l'apprentissage instrumental d'abeilles en vol libre et le conditionnement classique du réflexe d'extension du proboscis d'abeilles en contention. Puisque les 2 niveaux sont nécessaires pour comprendre l'apprentissage dans le contexte naturel, il est très important de s'assurer que c'est le même type d'apprentissage qui est étudié dans les 2 approches. En termes de théories de l'apprentissage, cela veut dire qu'il faut clarifier la nature des associations qui se forment au cours des comportements liés au butinage et pendant le conditionnement des abeilles en contention. Dans une situation de conditionnement classique, des associations directes se forment entre les divers stimuli, tandis que, chez les abeilles en vol libre, l'isolement des associations stimulus-renforcement nécessite une analyse du rôle des différents stimuli qui caractérisent un lieu de nourrissement, de leur relation les uns aux autres, au comportement opérant et à la qualité de la récompense obtenue.

Dans ce contexte, une approche récente utilisant des abeilles en vol libre semble prometteuse (Greggers et Menzel, 1993). Le comportement de butinage d'abeilles individuelles a été analysé à l'aide d'un dispositif formé de 4 nourrisseurs artificiels installés dans une prairie et présentant une situation dynamique de récompense (fig 
1). Tous les paramètres du comportement qui caractérisent une séquence de visites ont été contrôlés. L'abeille adapte son comportement de choix à la situation de récompense progressive (fig 2), ce qui indique la participation des processus d'apprentissage. Puisqu'il y a à la fois les paramètres du comportement, qui ne dépendent que de l'expérience à chaque nourrisseur artificiel, et les autres, qui en sont totalement indépendants (tableau I), on peut en conclure que les paramètres de la mémoire spécifiques des nourrisseurs et ceux qui sont non spécifiques guident le comportement de choix. En utilisant le comportement d'adaptation comme indicateur sensible de la mémoire associative, ce dispositif expérimental offre la possibilité d'étudier directement le rôle des stimuli et leur influence sur la formation des associations. Les essais préliminaires indiquent que si tous les stimuli et les repères topographiques proches sont enlevés, on n'observe pas d'adaptation, c'est-à-dire pas d'apprentissage associatif. Cela permet d'introduire séparément les stimuli étudiés.

Au niveau cellulaire, des enregistrements intracellulaires répétés de neurones identifiés permettent d'étudier le comportement de réponse de neurones individuels pendant les paradigmes de l'apprentissage olfactif. L'activité des potentiels d'action évoqués dans le neurone VUMmx1 peut remplacer la récompense de saccharose pendant le conditionnement olfactif classique (Hammer, 1991). Ce neurone a son origine dans le ganglion sous-œsophagien et se projette dans différentes régions du neuropile du cerveau, qui contiennent également des neurones des voies du traitement des odeurs. Le neurone PE1 assure des connections entre les structures du cerveau qui sont des sites éventuels de la formation de la mémoire olfactive (Mauelshagen, 1993; fig 3). L'application de paradigmes d'apprentissage simples, qui dans les expériences comportementales provoquent l'extension du proboscis en réponse à des odeurs, conduit à des modifications de la réponse qui sont spécifiques du paradigme d'apprentissage appliqué (tableau II). Jusqu'à présent, toutes les modifications observées étaient passagères, suggérant que le neurone PE1 n'est pas le site de stockage de la mémoire à long terme, mais qu'il est impliqué dans une phase dynamique brève au cours de la consolidation de la mémoire. L'électrophysiologie pourrait donc être un outil puissant pour décrire la dynamique temporelle et les mécanismes d'apprentissage à condition que les résultats soient inclus dans un contexte de données issues d'études comportementales sur des abeilles en vol libre.

apprentissage instrumental / conditionnement classique / apprentissage associatif

\section{Zusammenfassung - Experimenteller} Zugang zu assoziativem Lernen. Der gegenwärtige vielschichtige Ansatz zur Erforschung von Lernen und Gedächtnis bei der Honigbiene stützt sich auf 2 fundamentell verschiedene Aspekte des Lernverhaltens: auf das instrumentelle Lernen freifliegender Bienen und auf die klassische Konditionierung des Rüsselreflexes bei fixierten Bienen. Da beide Zugänge notwendig sind, um Lernen im natürlichen Kontext zu verstehen, muß sichergestellt werden, daß in beiden Fällen vergleichbare Arten des Lernens untersucht werden. Im lerntheoretischen Sinn bedeutet das, die Art der Assoziationen während des Sammelverhaltens und während der Konditionierung zu bestimmen. In einer klassischen Konditionierungssituation können Assoziationen nur zwischen verschiedenen Stimuli auftreten, während bei freifliegenden Bienen die Isolierung solcher Assoziationen eine Analyse der Stimuli erfordert, die den Futter- 
platz charakterisieren, um ihren Zusammenhang untereinander, mit dem operanten Verhalten und mit der Qualität der Belohnung zu erfassen.

In diesem Zusammenhang scheint ein neuerer Versuchsansatz vielversprechend (Greggers und Menzel, 1993). Auf einer Wiese mit vier künstlichen Blüten wurde das Sammelverhalten einzelner Bienen in einer dynamischen Belohnungssituation (Abb 1) aufgezeichnet. Dies ermöglichte die Analyse aller Verhaltensparameter, die während einer Abfolge von Blütenbesuchen relevant sind. Die lerninduzierte Anpassung der Biene an die Belohnungssituation äußert sich in einem "Matching"Verhalten (Abb 2). Da es sowohl Verhaltensparameter gibt, die nur von der jeweiligen individuellen Blüte abhängen, als auch solche, die von den individuellen Blüten völlig unbhängig sind (Tabelle I), kann man daraus schließen, daß das Entscheidungsverhalten der Biene von blütenabhängigen und blütenunabhängigen Gedächtniskomponenten bestimmt wird. Da das "Matching"-Verhalten als empfindlicher Gedächtnis-Indikator benutzt werden kann, ermöglicht diese experimentelle Apparatur die gezielte Analyse der relevanten Stimuli und deren Rolle bei der Gedächtnisbildung. Vorläufige Ergebnisse zeigen, daß kein "Matching"-Verhalten auftritt, wenn alle Stimuli und nahen Landmarken entfernt werden. Das ermöglicht, die zu untersuchenden Stimuli getrennt einzuführen.

Auf der zellulären Ebene erlauben gezielte intrazelluläre Ableitungen aus identifizierten Neuronen die Analyse von Reaktionsveränderungen als Folge olfaktorischer Lernparadigmen. Evozierte Aktivität im VUMmx1-Neuron kann die Zuckerwasser-Belohnung während einer klassischen Duftkonditionierung ersetzen (Hammer, 1991). Dieses Neuron hat seinen Ursprung im Unterschlundganglion und verzweigt in mehreren Neuropilbereichen des Gehirns, die außerdem Duft-prozessierende Neuro- nen enthalten. Das PE1-Neuron verknüpft Gehirnbereiche, die als Orte der Gedächtnisbildung in Frage kommen (Mauelshagen, 1993; Abb 3). Die Anwendung von einfachen Lernparadigmen, die in Verhaltensversuchen zum Rüsselreflex auf Duftstimuli führen, bewirkt eine Veränderung der Duftantwort dieses Neurons, die für die jeweilige Stimuluskonfiguration spezifisch ist (Tabelle II). Da die bisher gemessenen Reaktionsveränderungen nur vorübergehend waren, ist das PE1-Neuron wahrscheinlich kein Ort lang anhaltender Gedächtnisspeicherung, sondern ist eher an einem kurzfristigen und dynamischen Prozess während der Gedächtniskonsolidierung beteiligt.

Somit könnte besonders die Elektrophysiologie im Hinblick auf die Beschreibung von zeitlichen Dynamiken und die der Gedächtnisbildung zugrundeliegenden Mechanimen sehr erfolgreich sein, vorausgesetzt die Ergebnisse können im Rahmen der Gedächtnisphaenomene frei-fliegender Bienen interpretiert werden.

\section{Instrumentelles Lernen / klassische Konditionierung / assoziatives Lernen}

\section{REFERENCES}

Altfelder K, Müller U (1991) Cyclic nucleotidedependent protein kinases in the neural tissue of the honeybee, Apis mellifera. Insect Biochem 21 (5), 487-494

Altfelder K, Müller U, Menzel R (1991) Ca/ calmodulin and $\mathrm{Ca}$ /phospholipid-dependent protein kinases in the neural tissue of the honeybee, Apis mellifera. Insect Biochem 21 (5), 479-486

Bicker G (1993) Chemical architecture of antennal apthways mediating proboscis extension learning in the honeybee. Apidologie 24 (3)

Bitterman ME (1988) Vertebrate-invertebrate comparisons. NATO ASI Ser Intell Evol Biol 17, 251-275 
Bitterman ME, Menzel R, Fietz A, Schäfer S (1983) Classical conditioning of proboscis extension in honeybees (Apis mellifera). $J$ Comp Psychol 97, 107-119

Braun G, Bicker G (1992) Habituation of an appetitive reflex in the honeybee. $J$ Neurophysio/67(3), 588-598

Colwill RM, Rescorla RA (1986) Associative structures in instrumental learning. In: The Psychology of Learning and Motivation (Bower GH, ed) Academic Press, New York, 55104

Couvillon PA, Leiato TG, Bitterman ME (1991) Learning by honeybees (Apis mellifera) on arrival at and departure from a feeding place. J Comp Psychol 105(2), 177-184

Crow T, Forrester J (1990) Inhibition of protein synthesis blocks long-term enhancement of generator potentials produced by one-trial in vivo conditioning in Hermissenda. Proc Natl Acad Sci USA 87, 4490-4494

De Jong R, Pham-Delègue M-H (1991) Electroantennogram responses related to olfactory conditioning in the honey bee (Apis mellifera ligustica). Jinsect Physiol 37(4), 319-324

Erber J (1978) Response characteristics and after effects of multimodal neurons in the mushroom body area of the honeybee. Physiol Entomol 3, 77-89

Erber J (1980) Neural correlates of nonassociative and associative learning in the honey bee. Verh Dtsch Zool Ges 250

Erber J (1981) Neural correlates of learning in the honeybee. Trends Neurosci 4, 270-272

Erber J (1983) The search for neural correlates of learning in the honey bee. In: Neuroethology and Behavioral Physiology (Huber F, Markl H, eds) Springer, Berlin 216-227

Erber J, Masuhr T, Menzel R (1980) Localization of short-term memory in the brain of the bee, Apis mellifera. Physiol Entomol 5, 343358

Erber J, Schildberger K (1980) Conditioning of an antennal reflex to visual stimuli in bees (Apis mellifera L). J Comp Physiol 135, 217225

Frisch $\mathrm{K}$ von (1967) The Dance Language and Orientation of Bees. Harvard Univ Press, Cambridge, MA

Gould JL (1984) The natural history of honey bee learning. In: The Biology of Learning
(Marler $\mathrm{P}$, Terrace $\mathrm{H}$, eds) Springer, Berlin, 89-114

Gould JL (1986) The biology of learning. Annu Rev Psychol 37, 163-192

Greggers U (1989) Optimizing strategies in choice behaviour in the honeybee. In: Neural Mechanisms of Behavior: Proc 2nd Int Congr Neuroethology (Erber J, Menzel R, Pflüger HJ, Todt D, eds) Georg Thieme, Stuttgart, 219

Greggers U, Menzel R (1993) Memory dynamics and foraging strategies of honeybees. Behav Ecol Sociobiol 32, 17-29

Gronenberg W (1984) Das Protocerebrum der Honigbiene im Bereich des Pilzkörpers - eine neurophysiologisch-anatomische Charakterisierung. Dissertation, FU Berlin

Gronenberg W (1987) Anatomical and physiological properties of feedback neurons of the mushroom bodies in the bee brain. Exp Biol 46, 115-125

Grossmann K (1970) Erlernen von Farbreizen an der Futterquelle durch Honigbienen während des Anfluges und während des Saugens. Z Tierpsychol 27, 553-562

Grossmann KE (1971) Belohnungsverzögerung beim Erlernen einer Farbe an einer künstlichen Futterstelle durch Honigbienen. $Z$ Tierpsychol 29, 28-41

Grossmann KE (1973) Continuous, fixed-ratio, and fixed-interval reinforcement in honey bees. J Exp Anal Behav 20, 105-109

Hammer M (1991) Analyse der funtionellen Rolle des Neurons VUMmx1 bei der klassischen Konditionierung des Rüsselreflexes der Biene. Dissertation, FU Berlin

Hannes F (1930) Über die verschiedenen Arten des "Lernens" der Honigbiene und der Insekten überhaupt. Zool Jahrb Abt Allg Zool Physiol Tiere 47, 89-150

Homberg $U$ (1984) Processing of antennal information in extrinsic mushroom body neurons of the bee brain. J Comp Physiol A 154, 825836

Homberg U and Erber J (1979) Response characteristics and identification of extrinsic mushroom body neurons of the bee. $Z$ Naturforsch 34, 612-615

Kuwabara M (1957) Bildung des bedingten Reflexes von Pavlovs Typus bei der Honigbiene, Apis mellifica. I Fac Sci Hokkaido Univ Ser VI Zool 13, 458-464 
Lehrer M (1991) Bees which turn back and look. Naturwissenschaften 78, 274-276

Lieke E (1991) Asymmetric inhibitory interactions in the antennal lobes of honeybees revealed by real-time optical imaging. Soc Neurosci Abstr 17, 640

Lieke $E$ (1993) Optical recording of neuronal activity in the insect CNS: odorant coding by the antennal lobes of honeybees. Eur J Neurosci 5, 49-55

Lindauer M (1963) Allgemeine Sinnesphysiologie. Orientierung im Raum. Fortschr Zool 16, $58-140$

Masuhr T (1976) Lokalisation und Funktion des Kurzzeitgedächtnisses der Honigbiene, Apis mellifica L. Dissertation, TH Darmstadt

Mauelshagen J (1993) Neural correlates of olfactory learning paradigms in an identified neuron in the honey bee brain. J Neurophysiol 69 (2), 609-625

Menzel R (1968) Das Gedächtnis der Honigbiene für Spektralfarben. I. Kurzzeitiges und langzeitiges Behalten. Z Vgl Physiol 60, 82102

Menzel R (1987) Memory traces in honeybees. In: Neurobiology and Behavior of Honeybees (Menzel R, Mercer A, eds) Springer, Berlin, 310-325

Menzel R (1990) Learning, memory, and cognition in honey bees. In : Neurobiology of Comparative Cognition (Kesner RP, Olten DS, eds) Erlbaum Inc, Hillsdale, NJ, 237-292

Menzel R, Bitterman ME (1983) Learning by honey bees in an unnatural situation. In: $\mathrm{Be}$ havioral Physiology and Neuro-Ethology: Roots and Growing Points (Huber F, Markl H, eds) Springer, Berlin, 206-215

Menzel R, Erber J, Masuhr T (1974) Learning and memory in the honeybee. In: Experimental Analysis of Insect Behaviour (BartonBrowne L, ed) Springer, Berlin, 195-217

Menzel R, Hammer M, Braun G, Mauelshagen $J$, Sugawa M (1991) Neurobiology of learning and memory in honeybees. In: The Behavior and Physiology of Bees (Goodman LJ, Fisher RC, eds) CAB Int, Wallingford, UK, 323-251

Menzel R, Greggers U, Hammer M (1993) Functional organization of appetitive learning and memory in a generalist pollinator, the honey bee. In: Insect Learning - Ecology and Evolutionary Perspectives (Papaj DR, Lewis AC, eds) Chapman and Hall, New York, 79-125
Mercer AR, Menzel R (1982) The effects of biogenic amines on conditioned and unconditioned responses to olfactory stimuli in the honeybee, Apis mellifera. J Comp Physiol 145, 363-368

Mercer A, Mobbs PG, Evans PD, Davenport A (1983) Biogenic amines in the brain of the honey bee, Apis mellifera. Cell Tissue Res 234, 655-677

Michelsen DB (1988) Catecholamines affect storage and retrieval of conditioned odour stimuli in honey bees. Comp Biochem Physiol 91C, 479-482

Mobbs PG (1982) The brain of the honeybee Apis mellifera I.The connections and spatial organization of the mushroom bodies. Phil Trans R Soc Lond B 298, 309-354

Mobbs PG (1984) Neural networks in the mushroom bodies of the honeybee. J Insect Physio/ 30, 43-58

Mobbs PG (1985) Brain structure. In: Comprehensive Insect Physiology Biochemistry and Pharmacology (Kerkut GA, Gilbert LI, eds) Pergamon Press, Oxford, 299-370

Müller U, Altfelder K (1991) The Ca-dependent proteolytic system - calpain-calpastatin - in the neural tissue of the honeybee Apis mellifera. Insect Neurochem 21(5), 473-477

Opfinger E (1931) Über die Orientierung der Biene an der Futterquelle. $Z$ vergl Physiol 15, 432-487

Pavlov IP (1927) Conditioned Reflexes. Oxford Univ Press, London

Rehder V (1987) Quantification of the honeybee's proboscis reflex by electromyographic recordings. J Insect Physio/ 33, 501-507

Rehder V (1988) A neuroanatomical map of the suboesophageal and prothoracic ganglia of the honey bee (Apis mellifera). Proc $R$ Soc Lond 235, 179-202

Rehder $V(1989)$ Sensory pathways and motoneurons of the proboscis reflex in the suboesophageal ganglion of the honey bee. J Comp Neurol 279, 499-513

Rybak J (1987) Die morphologische Charakterisierung von alpha-Lobus extrinsischen $\mathrm{Neu}$ ronen. Diplomarbeit, FU Berlin

Sahley CL, Gelperin A, Rudy JW (1981) Onetrial associative learning modifies food odor preferences of a terrestrial mollusc. Proc Natl Acad Sci USA 78, 640-642 
Schäfer S, Rosenboom H, Menzel R (1993) Ionic currents of identified neurons from the mushroom bodies of the honeybee. In: Beiträge zur 21. Göttinger Neurobiologentagung. Thieme, Stuttgart (abstr)

Sigurdson JE (1981a) Methods and designs automated discrete techniques of appetitive conditioning in honey bees. Behav Res Methods Instrum 13, 1-10

Sigurdson JE (1981b) Measurement of consummatory behavior in honey bees. Behav Res Methods Instrum 13, 308-310

Skinner BF (1938) The Behavior of Organisms. Appleton-Century-Crofts, New York

Smith BH, Menzel R (1989a) The use of electromygram recordings to quantify odorant discrimination in the honey bee, Apis mellifera. $J$ Insect Physio/ 35, 369-375

Smith B, Menzel R (1989b) An analysis of variability in the feeding motor program of the honey bee: the role of learning in releasing a modal action pattern. Ethology 82, 68-81
Smith BH (1991) The olfactory memory of the honeybee Apis mellifera. I. Odorant modulation of short- and intermediate-term memory after single-trial conditioning. J Exp Biol 161, 367-382

Smith BH, Abramson Cl, Tobin TR (1991) Conditional withholding of proboscis extension in honeybees (Apis mellifera) during discriminative punishment. J Comp Psychol 105(4), 345-356

Staddon JE (1983) Adaptive Behavior and Learning. Cambridge Univ Press, New York

Sugawa M (1986) Zeitliche Dynamik und Lokalisation des Engraumes im Honigbienengehirn (Apis mellifera). Diploma Thesis, TU Berlin

Vareschi E (1971) Duftunterscheidung bei der Honigbiene - Einzelzell-Ableitungen und $\mathrm{Ve}$ rhaltensreaktionen. $Z$ vergl Physiol 75, 143-173

Wittstock S, Kaatz HH (1993) Inhibition of protein synthesis by cyclohemimide does not affect formation of long-term memory in honey bees after olfactory conditioning. J Neurosci (in press) 